\title{
Studies on the Hypothalamic Neurohumoral Factor with Special Reference to the Thyrotropin Releasing Factor
}

\author{
Minoru ASAMI \\ The 2nd Department of Internal Medicine, Kobe University, School of Medicine, \\ Kobe, Japan (Director : Professor Shozo Tsuji M.D.)
}

Recently, a number of neuroendocrinological studies have revealed that certain releasing factors play an essential role in the regulation of pituitary tropic hormone secretion. With regard to T R F (Thyrotropin Releasing Factor) there is also a great deal of evidence indicating its existence, but the nature of $\mathrm{T} \mathrm{R} \mathrm{F} \mathrm{is} \mathrm{not} \mathrm{quite} \mathrm{clear.} \mathrm{The} \mathrm{author} \mathrm{has} \mathrm{thus}$ tried to isolate active principle acting as TRF from bovine hypothalamus and to clarify the nature of TRF.

Bovine hypothalamus (anterior part and posterior part) and cerebral cortex were extracted by the method according to Kamm Aldrich which was reported as an extracting method for posterior pituitary hormones. These crude extracts were injected into the rats, and thyroidal effect was estimated by the Leblond's method and antidiuretic effect was tested by Van Dyke's method. Distinct thyroidal effect and antidiuretic activity were found in the crude extract of the anterior hypothalamus, but not in the extract of the posterior hypothalamus and cerebral cortex. The thyroidal effect of crude extract was not observed in the hypophysectomized rat. And plasma TSH activity after injection of these crude extracts in dogs, increased only in the case of anterior hypothalamic extract. Judging from these phenomena it was considered that hypothalamic extract acted via hypophyseal TSH.

The crude anterior hypothalamic extract was then fractionated by DEAE-Sephadex A-50 column using phosphate buffer with stepwise increasing ion-density. Five fractions, i.e., A, B, C, D and E were obtained. These 5 fractions were tested thyroidal effect, antidiuretic activity and TRF activity.

These 5 fractions were injected into the rat and thyroidal ${ }^{131}$ I release was determined by Brown-Grant's method. Most significant ${ }^{131} \mathrm{I}$ release was observed after injection of fraction $\mathrm{D}$ and a very slight increase after injection of fraction $\mathrm{B}$, but in hypophysectomized rats the thyroidal effect of fraction $\mathrm{D}$ was not observed. $\mathrm{ADH}$ activity was seen in fraction D most significantly and slightly in fraction A when estimated by Dicker's method. To determine TRF activity these 5 fractions were administered to the rats intravenously and plasma TSH levels were followed up by Mc Kenzie method. A marked increase of plasma TSH level was observed only after injection of fraction D.

It was verified that fraction $\mathrm{D}$ did not contain any TSH contamination and it did not inhibit metabolic degradation of TSH in peripheral tissure, and furthermore, this material did not act via endogenous TRF but directly on the pituitary itsself. 
Thus, the author has clearly shown that the thyrotropin releasing effect of fraction $\mathrm{D}$ is of a nature quite specific. A chromatographical study of fraction D showed that this fraction is a sort of biologically active peptide, but is different from known active amines and peptides in biological and chromatographic behavior.

(See pp. 189 206) 


\section{視床下部液性支配因子 \\ 一特に TSH 放出因子一に関する研究}

神戸大学医学部第二内科 (指導 辻 昇三教授)

阿佐美実

（昭和44年12月18日受付）

視床下部にその存在が想定されている TSH 放出因子 (TRF) の抽出分離を試み, 且つTRF の本 態を確めるために，大量の牛視床下部を Kamm Aldrich の方法で抽出し，更に DEAE-Sephadex A50 を使用したカラムクロマトにより分画化して得られた D 分画に特異的な TRF 効果を認めた。 TRF の 本態は後葉ホルモンや既知の活性アミン類やPeptide とは異つた特異的なものである事を示した.

緒

言

外界刺激や環境の変化が個体の内分泌機能に影響を与えているととは,古くより知られている所である.下 垂体甲状腺系もての例外ではなく，甲状腺疾患が外界や環境の変化により影響されている事は古くより認め られている. そして, 近年の Neuroendocrinology の発達により, 視床下部が下垂体前葉の機能を支配して いる事が明らかとなるにつれ，外界と個体との反応が，外界一神経系一視床下部一下垂体一内分泌系といつた 一連の反応形式で理解されるようになつて来た。そして，神経系と内分泌系の接触点という意味で，視床下 部か脚光を浴びてきたが，前葉の分泌神経の存在が全般としては否定されている今日では，視床下部の内分 泌機能に対する役割の一つは，Feed Back 機構に関連して，下垂体門脈を介した液性因子を前葉に送りて む機能が想定されている. そして, 近年, 視床下部の液性因子の探求もようやく試みられ, 視床下部に RF (Releasing Factor) を認めたといら報告も散見されるようになつてきた。 ての RF の研究で最も早く手の つけられたのが GRF であり，その本態は後葉ホルモン類似の Basic Peptide であると想定されている. 所が TSH 亿対する視床下部液性因子 (TRF) の探求は，未だ殆んぞ手がつけられておらず，その本態は 勿諭, その存在の立証すら確認されていない現状である. それ故, 視床下部抽出物よりTRF の探求を行 つた報告は極めて少ない.

そこで著者はV Vasopressin の抽出方法に従へば，類似した Peptide も contaminant として抽出されてく るものと考光，牛視床下部を Kamm Aldrich' ${ }^{1)}$ の方法で抽出を行い，更にカラムクロマトグラフィにより精 製を行い，各々の抽出物について TRF 効果，抗利尿効果を検討し，みるべき成績をあげたので以下に報告 する.

\section{第 1 章 実験対象亡実験方法}

\section{第 1 節 実験対象}

実験対象としては，犬，ラット，マウスを使用した。 犬は体重 $8 \sim 12 \mathrm{~kg}$ の雄成犬を十分にならして使用 した。 ラットはウィスター純系の雄ラットの体重 150〜200g のものを使用した. マウスは DD 系の雌マウ ス（体重 $15 \pm 1 \mathrm{~g}$ ）を使用した。実験動物は環境, 温度, 湿度, 照明等を常に一定に保つように努力し, 特 に食餌のヨード含有量を一定ならしめるよう考慮を払つた。

\section{第 2 節 実験方法}




\section{1 ) 抗利尿効果（犬）}

犬を用いる抗利尿效果の判定は兩側輸尿管外瘦造設術を行つた犬について, Van Dyke $\left.{ }^{2}\right)$ の方法に準じて行 つた。即ち，犬の両側輸泉管を取り出し，腎側にポリエチレンチューブを雨入して外瘦を作り，術後数日を経 たのち実験に供した。実験当日は絶食とし，ペントバルビタールソーダ麻酔下で, 胃管により約 $500 \mathrm{cc}$ 水を 注入し，その後 5 分毎に尿量を測定し，尿量の一定化してきた所で検体を静脈内に投与した。 そして，検体投 与前 15 分間の 1 分当り尿量を $\mathrm{A}$, 検体投与後 15 分間の 1 分当り尿量を $\mathrm{B}$ とするとき $\frac{\mathrm{A}-\mathrm{B}}{\mathrm{A}} \times 100$ を算出 し，てれを便宣上，尿量減少率 (Antidiuretic Index) という表現で記した。

2 ) 抗利尿効果 (ラット)

ラットを用いた抗利尿効果の測定は Dicker $^{3)}$ 及び糸賀の ${ }^{4)}$ 方法に準じて行つた。即ち，24時間水のみを投 与したラットに，12\%エタノール5.0cc/100g B.W. を経口的に投与して麻酷を行い，膀脱カテーテルにより 持続的に採尿する．尚，排尿量にひとしく $2 \%$ タノールを経口的に投与する．尿量の一定してきた時に尾 静脈により検体を静脈内に投与し $\frac{\text { 検体投与後 } 10 \text { 分間の尿量 }}{\text { 検体投与前10分間の尿量 }} \times 100=\mathrm{ADR}$ (Antidiuretic Response) で 表した。

\section{3 ）ラット下垂体甲状腺機能指標 ${ }^{576)}$}

i ) 甲状腺 ${ }^{131} \mathrm{I}$ 摂取率

$I^{131} 25 c \mu$ を $0.5 \mathrm{cc}$ の生理的食塩水に溶解して, ラットの腹腔内に投与し, 正確に 24 時間後に心臟穿刺に より失血死せしめた後, 甲状腺の左葉を摘出秤量し， $2 \mathrm{~N}$ 苛性ソーダ $10 \mathrm{cc}$ と共に加熱溶解し，正確にその $1 \mathrm{cc}$ をとり乾燥後 GM 管で計測した。

ii ) $\mathrm{PB}{ }^{131} \mathrm{I}$ 転換率

上記の血清 $0.5 \mathrm{cc}$ を $10 \%$ 硫酸亚鉛と $0.5 \mathrm{~N}$ 苛性ソーダで除蛋白洗涤した沈澱物を， $2 \mathrm{~N}$ 苛性ソーダで溶解 し, 乾燥後 GM 管で計測した. 別に血清 $0.5 \mathrm{cc}$ を乾燥させて GM管で計測し, その比を百分率で示した. iii) $\mathrm{T} / \mathrm{S}{ }^{131} \mathrm{I}$ 濃度比 上記ラットについて $\frac{\text { 甲状腺 } 1 \mathrm{mg} \text { の C.P.M }}{\text { 血清 } 0.1 \mathrm{cc} \text { の C.P.M }}$ で示した.

\section{$4 ）$ ラット ${ }^{131}$ 放出率測定}

Brown $\mathrm{Grant}^{7)}$ 及び Schreiber ${ }^{8)}$ の方法に準じて行つた。即ち，ラットに ${ }^{131} \mathrm{I} 25 \mu \mathrm{c}$ を腹腔内に投与した後， 莖部カウントの減衰のパターンを観察する方法である.ラットを軽くエーテルで麻酔した後，頸部を固定し， 直径 $1 \mathrm{~cm}$ の口径を有するコリメーターを取りつけた GM 管をラットの頸部に当てて計測する．ての場合， GM 管と甲状腺の距離は，厳密に一定にする必要がある．とのよいにして30秒ずつ 5 回計測を行い，その 平均值を頸部カウントとした。 ${ }^{131} \mathrm{I}$ 投与後，24時間目の頸部カウントを 100 とし，その後のカウントを百分 率で示し, 半対数グラフに ${ }^{131} \mathrm{I}$ 放出曲線を示した.

\section{5 ）ラット下垂体剔除法}

田中氏 ${ }^{9)}$ の脳下垂体剔除法に従つた。尚, 実験終了後, 下垂体のないととを確めた。

\section{6) 血獎 TSH}

i ）犬血獎 TSH 様活性の測定は牛甲状腺スライスを用いる in vitro の Bakke-小倉法 ${ }^{10)}$ とり測定した.

ii ) ラット血漿 TSH 活性

ラット血墏 TSH 活性の測定は in vivo の Mc Kenzie 法 ${ }^{11)}$ にり測定した. 即ち, 1 群 8 〜0匹の 早 マウス（体重 $15 \mathrm{~g}$ ）に $10 \mu \mathrm{c}$ の $^{131} \mathrm{I}$ を腹腔内に投与した後，正確に 4 時間及び24時間後にそれぞれ $10 \mu \mathrm{g} の$ $\mathrm{T}_{4}$ を皮下に投与する. 第 2 回目の $\mathrm{T}_{4}$ 投与後 48 時間を経て後, 一側眼静脈叢より正確に $0.2 \mathrm{cc}$ 採血し, ${ }^{131} \mathrm{I}$ 量を測定する. 次で尾静脈より $0.4 \mathrm{cc}$ の検体を投与し，その後 2 時間を経て，他側眼静脈叢より $0.2 \mathrm{cc}$ 採血 し ${ }^{131} \mathrm{I}$ 量を測定する.

$\frac{\text { 検体投与後 } 2 \text { 時間目の }{ }^{131} \mathrm{I} \text { 量 }}{\text { 検体投与前の }{ }^{131} \mathrm{I} \text { 量 }} \times 100$ で TSH 量を表した. 


\section{7 ）主な使用薬物}

Vasopressin : Pitressin (Parke Davis)

合成 Vasopressin : Lysine-8-Vasopressin, (Sandoz)

Arginin-8-Vasopressin (Sandoz)

TSH : Pretiron (Schering A.G.)

$\alpha$-MSH : (Schally's Laboratories)

\section{第 2 章 牛視床下部粗エキスの抗利尿効果並びに下垂体甲状腺系機能に対する影響}

\section{第 1 節 抽出方法}

屠殺後出来るだけ早期に牛視床下部を，粉末状にしたドライアイスで涷結せしめた後，血管を除去し，前 は視束交叉の前縁, 後は乳頭体後縁, 上は視床下溝, 下は下垂体柄の根元で下垂体と切り離した. この場合, 腺葉，神経葉は勿論のとと， 結節部も含まないよ うに注意した．横は中線より約 $0.5 \mathrm{~cm}$ の巾を切り とり，更に二分して前及び後視床下部とした。 そ して 1 回の抽出には約 100 頭づつを使用し, 総計約 一万頭の牛視床下部を使用した。抽出方法は (Fig. 1) 飞示すように Kamm Aldrich ${ }^{1)}$ の方法に準じて 行つた。即ち, 前及び後視床下部を秤量後, 希醋 酸水で加熱抽出を行い, 更に冷却せる希醋酸水で 抽出を二回くり返す．この抽出液を合して硫酸ア ン゙モンで塩析を行ない，蛋白成分を析出させる.

これを醋酸で抽出してェーテルと石油エーテル で有効成分を沈澱させた後, 醋酸抽出, エーテル 沈澱をくり返したものを視床下部粗エキスとした. 尚，対照として同じ牛の頭頂葉皮質をも同様の方 法で抽出した。抽出した粗エキスは, 乾燥デシケ 一ターに入れて冷暗所に保存し, 早期に実験に供 した．尚てのようにして抽出しうる粗エキスの量 は, 牛視床下部 $100 \mathrm{~g}$ より約 100 ないし $300 \mathrm{mg}$ 程 度であつた。

\section{第 2 節 抗利尿効果}

前及び 後視床下部粗エキス並びに大脳皮質抽出 物の一定量を秤量し, $0.5 \mathrm{cc}$ の生理的食塩水に溶解

Fig. 1. Preparation method of crude extract.

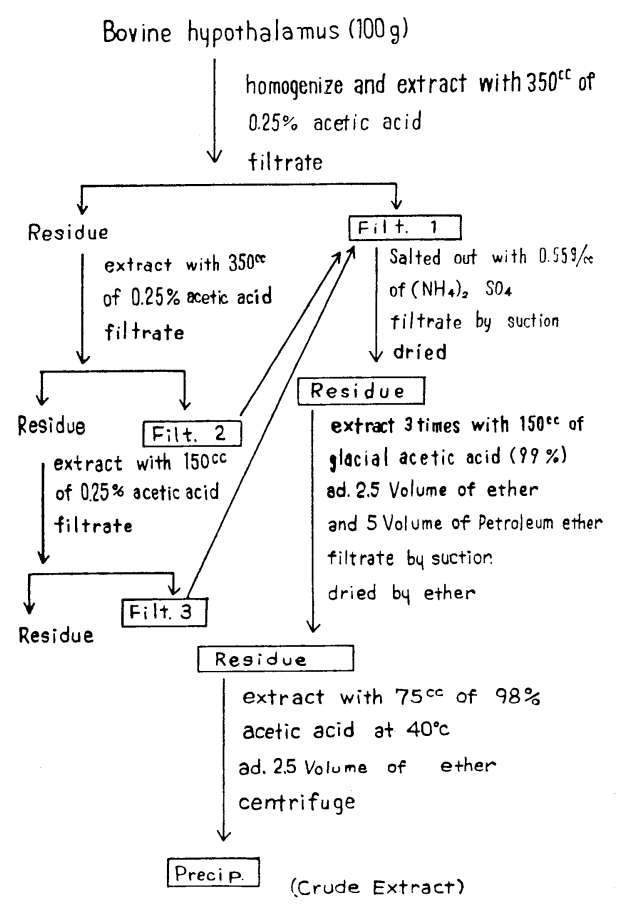
して十分に遠沈した後, その上清を輸尿管外慺を設定した犬の静脈内に投与した。

それぞれの検体を投与した場合の抗利尿効果は（Table 1) に示す様に，各抽出物とも投与量を増せば， その尿量减少率は多少増加の傾向を認めるが, 前視床下部粗エキス投与群は, 後視床下部粗エキス投与群や 皮質抽出物投与群にくらへてて, 極めて高い尿量減少効果を示している. 尚, 本法によるとPitressin 1 単位 は $52.2 \%$ 尿量诚少率を示し, 前視床下部粗エキス $5 \mathrm{mg}$ 投与の場合に近い抗利尿效果を示した。

\section{第 3 節 ラット下垂体甲状腺機能に対する影響}

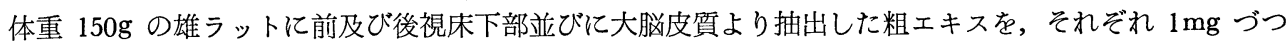
$0.5 \mathrm{cc}$ の生理的食塩水に浴解して, 5 日間筋内内に投与し, 最後の注射ののち 24 時間で失血死せしめた後, 第 1 章でのべた方法に従つて, 甲状腺重量, ${ }^{131} \mathrm{I}$ 摂取率, $\mathrm{PB}{ }^{131} \mathrm{I}$ 転換率, $\mathrm{T} / \mathrm{S}{ }^{131} \mathrm{I}$ 濃度比を測定した. 尚, 生理的食塩水を $0.5 \mathrm{cc}$ づつ 5 日間投与したものを対照群とした. 
Table 1. Antidiuretic effect of crude extracts

\begin{tabular}{l|c|c|c} 
Antidiuretic index $\%=\frac{\left(\begin{array}{c}\text { Urine Vol. of 15min. } \\
\text { before administ. }\end{array}\right)-\left(\begin{array}{c}\text { Urine Vol. of 15min. } \\
\text { after administ. }\end{array}\right)}{\left(\begin{array}{c}\text { Urine Vol. of 15min. } \\
\text { before administ. }\end{array}\right)} \times 100$ \\
\hline \hline \multirow{2}{*}{ Anterior hypothalamus } & Dosis & No. of animal & $\begin{array}{c}\text { Antidiuretic index } \% \\
\text { mean } \pm \text { S.E. }\end{array}$ \\
\hline Pitressin & $1.0 \mathrm{mg}$ & 5 & $52.2 \pm 2.4$ \\
\hline Posterior hypothalamus & $5.0 \mathrm{mg}$ & 5 & $37.0 \pm 8.0$ \\
& $2.5 \mathrm{mg}$ & 5 & $47.0 \pm 1.4$ \\
& $5.0 \mathrm{mg}$ & 6 & $52.0 \pm 11.5$ \\
\hline \multirow{2}{*}{ Gerebral cortex } & $2.5 \mathrm{mg}$ & 5 & $6.3 \pm 3.9$ \\
& $5.0 \mathrm{mg}$ & 5 & $6.4 \pm 4.6$ \\
\hline
\end{tabular}

Table 2. Effect of crude extracts on the function of thyroid gland in normal rats and hypophysectomized rats

\begin{tabular}{|c|c|c|c|c|c|c|}
\hline & & $\begin{array}{l}\text { No. of } \\
\text { rats }\end{array}$ & $\begin{array}{c}\text { Thyroid } \\
\text { weight } \\
\text { mg/B.W. }\end{array}$ & $\begin{array}{c}{ }^{131} \mathrm{I}-\mathrm{Uptake} \\
\%\end{array}$ & $\begin{array}{c}\text { PB }{ }^{131} \mathrm{I} \\
\text { Conversion } \\
\text { ratio }\end{array}$ & $\underset{\%}{\mathrm{~T} / \mathrm{S}}{ }^{131} \mathrm{I}$ \\
\hline \multirow{4}{*}{ Normal rats } & Saline (control) & 10 & $5.17 \pm 0.26^{*}$ & $26.0 \pm 0.81$ & $50.6 \pm 1.85$ & $22.7 \pm 1.35$ \\
\hline & $\begin{array}{c}\text { Anterior } \\
\text { hypothalamus }\end{array}$ & 7 & $\begin{array}{l}7.00 \pm 0.09 \\
\mathrm{P}<0.01^{* *}\end{array}$ & $\begin{array}{c}36.2 \pm 3.20 \\
\mathrm{P}<0.01\end{array}$ & $\begin{array}{c}57.0 \pm 2.11 \\
P=0.05\end{array}$ & $\begin{array}{c}27.8 \pm 1.61 \\
\mathrm{P}<0.05\end{array}$ \\
\hline & $\begin{array}{c}\text { Posterior } \\
\text { hypothalamus }\end{array}$ & 7. & $5.06 \pm 0.09$ & $27.4 \pm 3.40$ & $54.4 \pm 2.20$ & $22.6 \pm 2.20$ \\
\hline & Cerebral cortex & 7 & $6.10 \pm 0.05$ & $21.7 \pm 1.13$ & $48.2 \pm 4.76$ & $19.9 \pm 1.93$ \\
\hline \multirow{2}{*}{$\begin{array}{l}\text { Hypophyse- } \\
\text { ctomized rats }\end{array}$} & Saline (control) & 6 & $4.90 \pm 0.45$ & I $5.1 \pm 1.22$ & $25.3 \pm 1.64$ & $16.3 \pm 0.88$ \\
\hline & $\begin{array}{c}\text { Anterior } \\
\text { hypothalamus }\end{array}$ & 6 & $4.60 \pm 0.20$ & $15.1 \pm 1.63$ & $25.0 \pm 0.52$ & $16.0 \pm 0.65$ \\
\hline
\end{tabular}

$*$ mean \pm S.E. ** P-Value compared with control

その結果は (Table 2) に示すように, 前視床下部粗エキス投与群はそのいづれの指標に於ても, 後視床 下部粗エキス投与群や皮質粗エキス投与群，並びに生食を投与した対照群にくらべ，甲状腺機能を六進させ る作用のあることがわかる.

次にこの前視床下部粗エキスの甲状腺効果が，下垂体 TSH を介した作用であるか或いは，甲状腺への直 接作用であるのかを確めるために，垂剔ラットについて同様の実験を行つた. 即ち垂剔 5 日目より前視床下 部粗エキス $1 \mathrm{mg}$ を 5 日間筋肉内に投与したものと，生理的食塩水を 5 日間投与したものとについて甲状腺機 能を比較した．その結果は，(Table 2) に示しているように，垂剔ラットは正常ラットに比べ明らかに甲状 腺機能の低下を認めると共に, 前視床下部粗エキス投与群と生理的食塩水投与群の間には, その甲状機能に 有意の差を認めない. 即ち, 前視床下部粗エキスは垂剔ラットに対しては, 正常ラットに示した様な甲状腺 効果を示さない. それ故, 本抽出物は下垂体 TSH を介して甲状腺に㗢くものと考えられる.

\section{第 4 節 犬血獎 TSH 様活性に及ぼす影響}


前及び後視床下部, 並びに大脳皮質より抽出したそれぞれの粗エキス $2 \mathrm{mg}$ を $0.5 \mathrm{cc}$ の生理的食塩水に溶 解し, 雄成犬の頸静脈内に投与した。. そして, 投与前及び投与後, 30分, 60分, 120分, 亿他側頸静脈より 採血して, 血漿 TSH 様活性を Bakke-小倉法 ${ }^{10)}$ で測定した.

今, 検体投与前の TSH の值を 1 とし，その増減の倍率を半対数グラフに示すと，(Fig. 2) の様になる. 尚, 点線は增減の倍率の平均值である. この事から前視床下部粗エキスには, 後視床下部粗エキスや皮質エ キス投与群にくらべ血漿 TSH 様活性を上昇させる作用があるといえる.

Fig. 2. Effect of hypothalamic extracts on plasma TSH activity.

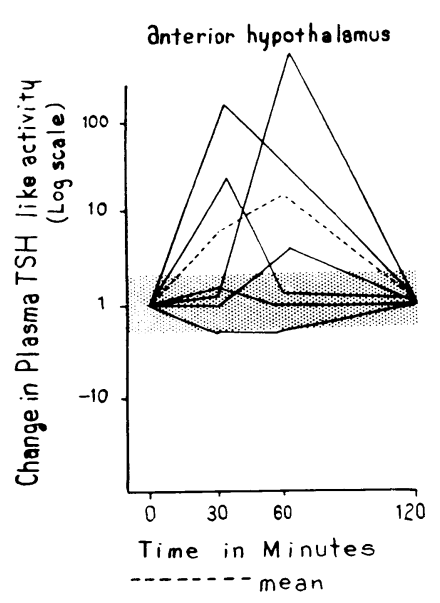

Posterior hypothal amus

Cerebral Cortex
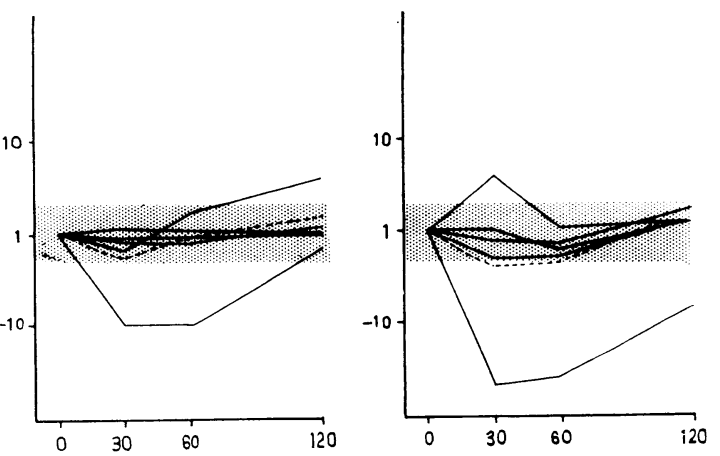

\section{第 5 節 粗エキスの電気泳動}

（方法） 東洋沪紙 $\mathrm{C}$ 号型電気泳動装置を用い, 濾紙は WhatmanNo. 1 を巾 $15 \mathrm{~cm}$, 長さ $35 \mathrm{~cm}$ に切り, $10^{\circ} \mathrm{C}$ の恒温室で泳動を行つた.

緩衝液としては Holt ${ }^{12}$ )のVeronal 緩衝液（ $\mathrm{pH} 8.6$, イオン強度 0.05$)$ を使用し， $5 \mathrm{~mA}$ 定電流のもとに 8 時間泳動を行つた。試料としては前視床下部粗エキスの分離を目的とし, TSH，血清等との平行泳動を行 つた.

泳動終了後の沪紙はアミド黒 ${ }^{13}$ により染色した。

（結果） 前視床下部粗エキスは電気泳動により，尚，5ケの分画に分離された. (Fig. 3) 今仮に，乙の5 ケの分画を陰極側よりそれぞれ，No.1，No.2，No.3，No.4，No.5分画とすると，No.1分画は陰極側と 移動し, No. 2 分画は原点附近にとどまり，No. $3 ，$ No. 4 , No. 5 分画は平行泳動した血清の ロブリンの間に移動している. 又, 平行泳動したTSH は No. 5 分画附近に移動する.

Fig. 3. Electrophoresis of crude extract from bovine anterior hypothalamus.

$$
\mathrm{PH} 8.6 \quad \mu \quad 0.05 \quad 0.5 \mathrm{~mA} / \mathrm{cm} \quad 7 \mathrm{hr}
$$

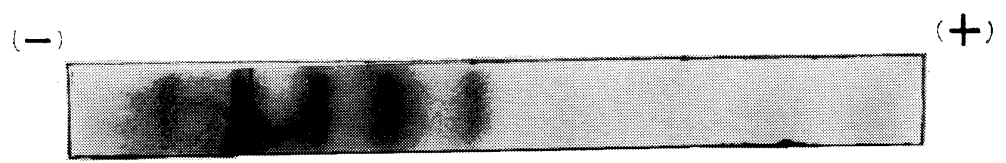

\section{小 括}

牛の前及び後視床下部並びに頭頂葉皮質を Kamm Aldrich の方法に準じて抽出を行い抗利尿効果, 甲状 腺効果を調べた所, 前視床下部粗エキスに於て, 抗利尿作用及び下垂体甲状腺機能元進効果を認めた。この 
前視床下部粗エキスは電気泳動により，尚，数ヶの分画に分離し得た。

第 3 章 牛視床下部精製分画の抗利尿効果並びに下垂体甲状腺系機能に対する影響

\section{第 1 節 DEAE-Sephadex による粗エキスの分画化}

従来，蛋白質ないし Peptide のクロマトには優れた方法がなかつたが，近年のゲル滤過法の導入により， これらの物質が比較的簡単に，しかも従来のイオン交換樹脂を用いた方法こ組み合せる事により，或程度十 分に分離しうるよう汇なつてきた。

（方法）内径 $2 \mathrm{~cm}$ ，長さ $1 \mathrm{~m}$ のカラムに DEAE-Sephadex A50 を $\mathrm{pH} 6.8,0.02 \mathrm{M}$ の燐酸紸衝液で平衝 化した後， $25 \mathrm{~cm}$ の高さに迄カラムに立填する．溶出はこの燐酸緩衝液にそれぞれ，0.07M，0.17M，0.38M，

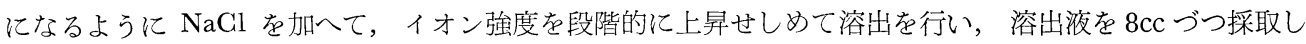
て $278 \mathrm{~m} \mu$ で吸光度を測定した.

（結果）乙のような方法で前視床下部粗エキスを分画化すると（Fig. 4) に示すように，A，B，C，D，E， の5 ケの分画に分離しうる。.てのうち，A分画はアミド黒により染色される。 その他の B. C. D. E. 分画 はニンヒドリン ${ }^{14)}$ では染色されるが，アミド黒では染色されない。

\section{第 2 節 各分画の抗利尿効果}

抗利尿効果の測定は Dicker ${ }^{3)}$ ，糸賀4) のラットを用いる方法によつた。本法を用いて 種々の量の Lysine Vasopressin，及び，視床下部それぞれの分画 $1 \mathrm{mg}$ を $0.5 \mathrm{cc}$ の生理的食塩水に溶解して，尾静脈より投与し， それぞれの抗利尿効果（ADR）の対数（Log. ADR）を表にすると（Table 3）の如くである.

今 Lysine Vasopressin について縦軸に Log. ADR をとり，横軸に投与 Vasopressin 単位をとり，縦 軸を $\mathrm{y} ，$ 横軸を $\mathrm{x}$ とすれば， $\mathrm{y}=1.988-2.5 \mathrm{x} \quad \gamma=-0.18$ の回帰方程式をえた（Fig.5) 尚，この式より算

Fig. 4. Fractionation of bovine hypothalamic extract on DEAE sephadex A 50.

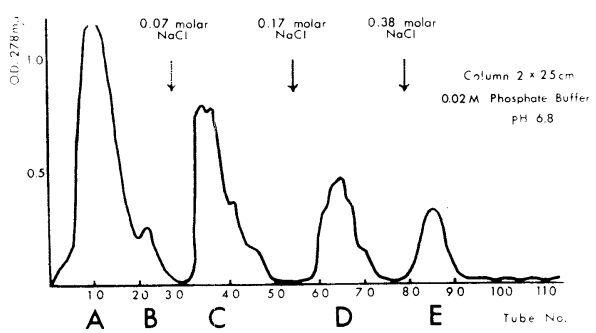

Fig. 5. Antidiuretic effect of various fractions.

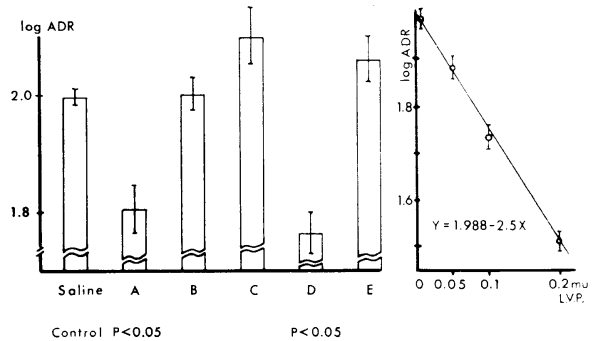

Table 3. Antidiuretic effect of lysine vasopressin and hypothalamic fractions

\begin{tabular}{l|c|c|c}
\hline \hline & Dosis & $\begin{array}{c}\text { Antidiuretic effect } \\
\text { Log. ADR \% }\end{array}$ & P \\
\hline \multirow{4}{*}{ Lysine vasopressin } & $0 \gamma$ & $2.00 \pm 0.014$ & Control \\
& $50 \gamma$ & $1.88 \pm 0.031$ & \\
& $100 \gamma$ & $1.70 \pm 0.018$ & \\
\hline \hline \multirow{5}{*}{ Hypothalamic fractions } & $200 \gamma$ & $1.51 \pm 0.018$ & \\
& A $1 \mathrm{mg}$ & $1.80 \pm 0.057$ & $0.05>\mathrm{P}>0.02$ \\
& B $1 \mathrm{mg}$ & $2.00 \pm 0.036$ & \\
& C $1 \mathrm{mg}$ & $2.14 \pm 0.061$ & $0.05>\mathbf{P}>0.02$ \\
& D $1 \mathrm{mg}$ & $1.77 \pm 0.065$ & \\
& $\mathrm{E} 1 \mathrm{mg}$ & $2.05 \pm 0.042$ & \\
\hline
\end{tabular}


定すれば，D分画 $1 \mathrm{mg}$ は約 $0.09 \mathrm{mu} ， \mathrm{~A}$ 分画 $1 \mathrm{mg}$ で約 $0.08 \mathrm{~m} . \mathrm{u} ， の$ Lysine Vasopressin 亿等しい抗利尿 活性を示すことになる. その他の $\mathrm{B}, \mathrm{C}, \mathrm{E}$, 分画には抗利尿活性は全く認められない.

\section{第 3 節 各分画のラット ${ }^{131} \mid$ 放出曲線に対する影響}

ラットに ${ }^{131} \mathrm{I}$ を投与して後，24時間後の頸部カウントを 100 とし，その後，48，72，96，120，時間後の 頸部カウントをそれぞれ\%で示したものを半対数グラフに示すと一直線になる. 又, ${ }^{131} \mathrm{I}$ 投与後48時間目に $0.5 \mathrm{cc}$ の生理的食塩水を筋肉内に投与した時も, その後の ${ }^{131} \mathrm{I}$ 放出曲線には何ら変動を認めない.

所が， ${ }^{131} \mathrm{I}$ 投与後48時間目に lu.s.p. の TSH を投与したものでは, ${ }^{131} \mathrm{I}$ 放出促進効果が著明に認められ る. 今, てれらの事実を数量的に表をすために, Schreiber らに従つて, 生理的食塩水投与後, 24 時間 ( ${ }^{131} I$ 投与後 72 時間) 及び 48 瞔間 ( ${ }^{131} \mathrm{I}$ 投与後 96 時間) 後の 頸部カウントを, 生理的食塩水投与直前 ${ }^{131} \mathrm{I}$ 投与 48時間目）の頸部カウントの百分率で示すと，それぞれ $81.1 \pm 0.75 \%$ 及び $68.4 \pm 1.63 \%$ という值になる.

所が，TSH を投与したものではての值が， $67.0 \pm 1.19 \%$ 及び， $51.5 \pm 2.15 \%$ となり $\mathrm{P}<0.01$ の危険率で TSH 飞 ${ }^{131} I$ 放出促進効果のあるととが分る．乙れらの結果を図示すると（Table 4) (Fig. 6) の如くであ る.

そこで, 視床下部よりの各分画 $1 \mathrm{mg}$ を $0.5 \mathrm{cc}$ の生理的食塩水に溶解し, 各群 8 ないし10匹づつ, ${ }^{131} \mathrm{I}$ 投 与後48時間目にラットの筋肉内に投与して, その後の ${ }^{131}$ I 放出曲線に与光る影響を追跡した。 この結果, $\mathrm{D}$ 分画投与群に於て著明な ${ }^{131} \mathrm{I}$ 放出促進効果か認められ， B 分画投与の場合にも有意の ${ }^{131} \mathrm{I}$ 放出促進効果 を認めている．そこでての事実の有意性を確めるために，検体投与後 24 時間及び48時間目の頸部カウントを， 検体投与直前の頸部カウントの百分率で示すと（Table 4) 及び (Fig. 7) の如く, D及びB分画には ${ }^{131}$ I 放 出促進効果がある事がわかる.

\section{第 4 節 Lysine Vasopressin 及び $\boldsymbol{\alpha}$-MSH $の{ }^{131} 1$ 放出曲線に対する影響}

前節迄の結果から D分画 $1 \mathrm{mg}$ は甲状腺 ${ }^{131} \mathrm{I}$ 放出促進効果を示し, 且つ, D分画 $1 \mathrm{mg}$ は約 $0.09 \mathrm{mu} の$ Lysine Vasopressin 亿相当する抗利尿活性がある事が判つた。そこでてのD分画の本態が Vasopressin で

Table 4. Effect of hypothalamic fractions lysine vasopressin and $\alpha-\mathrm{MSH}$ on thyroidal ${ }^{131} \mathrm{I}$ release

\begin{tabular}{|c|c|c|c|c|c|c|c|}
\hline & & Dosis & $\begin{array}{l}\text { No. of } \\
\text { rat }\end{array}$ & $\begin{array}{l}\% \text { of } 24 \mathrm{hrs} . \\
\text { after inject. }\end{array}$ & $\mathbf{P}$ & $\begin{array}{l}\% \text { of } 48 \mathrm{hrs} . \\
\text { after inject. }\end{array}$ & $\mathbf{P}$ \\
\hline \multicolumn{2}{|l|}{ Non treated } & - & 9 & $77.0 \pm 1.41$ & - & $62.9 \pm 0.71$ & 一 \\
\hline \multicolumn{2}{|l|}{ Saline } & $0.5 \mathrm{cc}$ & 10 & $81.1 \pm 0.75$ & Control & $68.4 \pm 1.63$ & Control \\
\hline \multicolumn{2}{|l|}{$\mathrm{TSH}$} & 1.0usp & 8 & $67.0 \pm 1.19$ & $<0.01$ & $51.5 \pm 2.15$ & $<0.01$ \\
\hline \multirow{5}{*}{$\begin{array}{l}\text { Hypothalamic } \\
\text { fractions }\end{array}$} & A & $1 \mathrm{mg}$ & 8 & $80.1 \pm 2.22$ & \multirow{3}{*}{$<0.01$} & $65.9 \pm 2.07$ & \multirow{3}{*}{$<0.01$} \\
\hline & B & $1 \mathrm{mg}$ & 10 & $72.5 \pm 1.92$ & & $59.8 \pm 2.37$ & \\
\hline & $\mathrm{C}$ & $1 \mathrm{mg}$ & 8 & $81.0 \pm 1.36$ & & $65.3 \pm 1.33$ & \\
\hline & $\mathrm{D}$ & $1 \mathrm{mg}$ & 10 & $67.7 \pm 2.01$ & \multirow[t]{2}{*}{$<0.01$} & $58.5 \pm 1.72$ & \multirow[t]{2}{*}{$<0.01$} \\
\hline & $\mathrm{E}$ & $1 \mathrm{mg}$ & 8 & $81.3 \pm 2.34$ & & $68.2 \pm 1.78$ & \\
\hline \multirow{5}{*}{\multicolumn{2}{|c|}{$\begin{array}{c}\text { Lysine } \\
\text { vasopressin }\end{array}$}} & $0.1 \mathrm{mu}$ & 7 & $80.6 \pm 0.9$ & \multirow[b]{5}{*}{$<0.02$} & $66.2 \pm 1.68$ & \multirow[b]{5}{*}{$<0.01$} \\
\hline & & $\operatorname{lmu}$ & 7 & $81.9 \pm 0.91$ & & $67.5 \pm 1.94$ & \\
\hline & & $10 \mathrm{mu}$ & 7 & $82.5 \pm 0.71$ & & $70.1 \pm 2.21$ & \\
\hline & & $100 \mathrm{mu}$ & 7 & $84.1 \pm 0.92$ & & $73.2 \pm 1.58$ & \\
\hline & & $1000 \mathrm{mu}$ & 10 & $74.0 \pm 2.46$ & & $59.8 \pm 2.30$ & \\
\hline \multirow{2}{*}{\multicolumn{2}{|c|}{$\alpha$-MSH }} & $50 \mu \mathrm{g}$ & 8 & $85.0 \pm 2.58$ & & $72.3 \pm 1.14$ & \\
\hline & & $300 \mu \mathrm{g}$ & 7 & $86.1 \pm 1.39$ & & $73.4 \pm 1.52$ & \\
\hline
\end{tabular}


Fig. 6. Effect of TSH on thyroidal ${ }^{131} \mathrm{I}$ release.
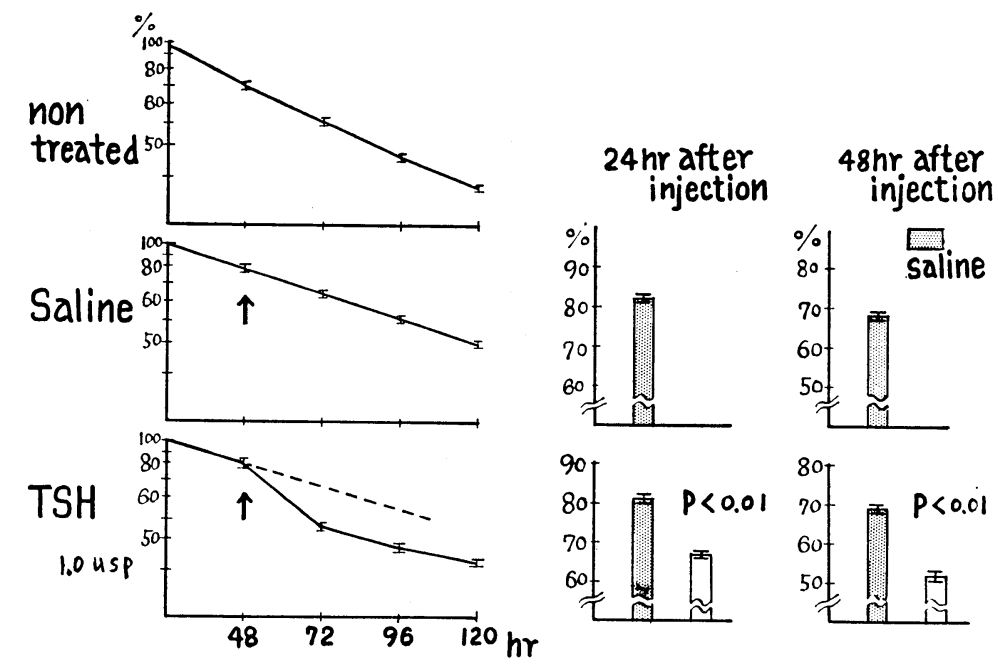

あるか否かを確めるために，逆に種々の量の Lysine Vasopressin を投与して, ${ }^{131} \mathrm{I}$ 放出曲線に 及ぼす影響を観察し, 又併せて $\alpha-\mathrm{MSH} の{ }^{131} \mathrm{I}$ 放 出曲線に対する影響を検討した. 方法は, 前節と 全く同じ方法をとり， ${ }^{131} \mathrm{I}$ 投与後48時間目にそれ ぞれ $0.1 \mathrm{mu}, 1 \mathrm{mu}, 10 \mathrm{mu}, 100 \mathrm{mu}, 1000 \mathrm{mu}$, の Lysine Vasopressin 及び $50 \mu \mathrm{g}, 300 \mu \mathrm{g}$ の $\alpha \mathrm{MSH}$ を，それぞれ $0.5 c c$ の生理的食塩水に溶解してラ ットの筋肉内に投与した.

その結果，検体投与後 24 時間， 48 時間目の ${ }^{131} \mathrm{I}$ 量を検体投与直前の頸部 ${ }^{131} \mathrm{I}$ 量の百分率で示すと (Table 4) の如くである. 即ち, Lysine Vasopressin そのものでは $100 \mathrm{mu}$ 迄を投与しても甲状 腺 ${ }^{131} \mathrm{I}$ 放出に影響を示さない. D分画 $1 \mathrm{mg}$ の抗利 尿活性の 10,000 倍以上に相当する $1000 \mathrm{mU}$ を投与 した時に於てのみ，わづかに甲状腺効果を示すに すぎない，それ故， D分画の ${ }^{131} \mathrm{I}$ 放出促進効果は Vasopressin によるものではないと考えられる. 又, $50 \mu \mathrm{g}, 300 \mu \mathrm{g}$ の $\alpha \mathrm{MSH}$ では甲状腺 ${ }^{131} \mathrm{I}$ 放出 に何等影響を認めなかつた。

Fig. 7. Effect of hypothalamic fractions on thyroidal ${ }^{131}$ I release

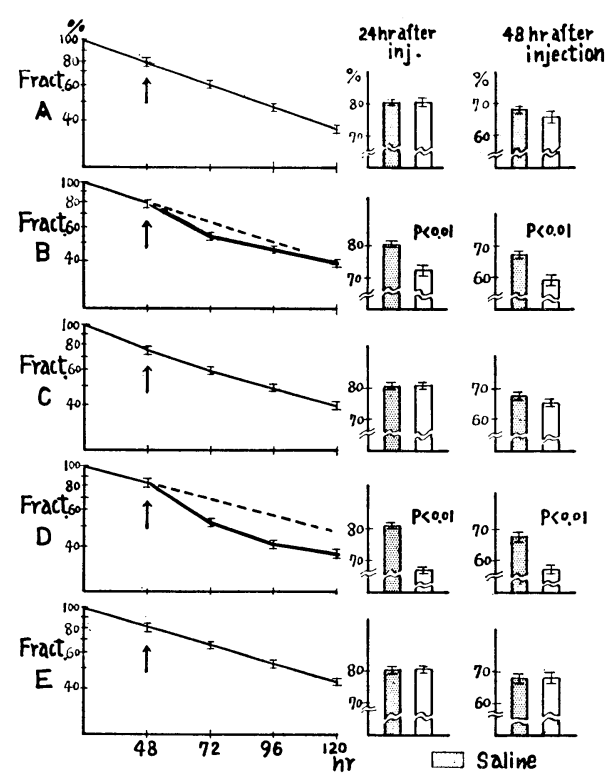

小 括

牛の前視床下粗エキスを DEAE-Sephadex A50 を用いたカラムクロマトで分画化すると, A, B, C, D, E, の 5 ケの分画が得られた。 てれらの内, 抗利尿活性はD分画, 次で A分画に認められ, 甲状腺 ${ }^{131} \mathrm{I}$ 放出促 進効果はD分画，次で B 分画に認められた．乙れらの結果を要約すると (Fig. 8) の如くである. 又, D分 画の本態はVasopressin そのものではないと考えられる. 
Fig. 8. The comparison of $\mathrm{ADH}$ activity and TRF activity ( ${ }^{131} \mathrm{I}$ release method) in various fractions.

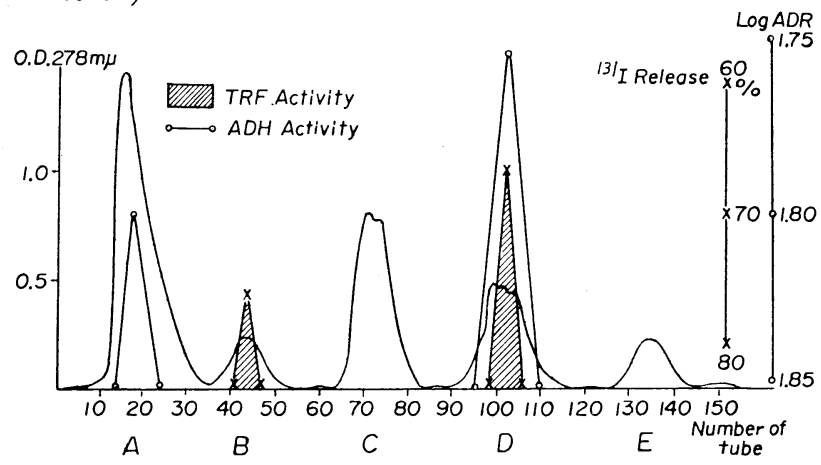

第 4 章 牛視床下部精製分画の TRF 効果について

\section{第 1 節 各分画のラット血獎 TSH 活性に及ぼす影響}

低ヨード食で飼育した体重 $150 \mathrm{~g}$ の雄ラットに， $\mathrm{T}_{3} 0.6 \mu \mathrm{g}$ の皮下注射を行つた後， 4 時間を経て，ペン トバルビタールソーダで麻酔し，頸静脈より $0.8 \mathrm{cc}$ のペリン採血を行い，直ちに検体をその静脈内に投与 し，投与後正確に 3 分， 6 分，12分後に他側の頸静脈より $0.8 \mathrm{cc}$ づつ採血する. この場合, 検体としては, $\mathrm{A}, \mathrm{B}, \mathrm{C}, \mathrm{D}, \mathrm{E}$ 各々の分画を $100 \mu \mathrm{g}$ づつ $0.4 \mathrm{cc}$ の生理的食塩水に溶解したものを用いた.

このようにして一群 6 〜 8 匹のラットより採血したそれぞれの血液を合して血漿を分離し，一夜水室に保 存した後, その血獎 TSH 活性を Mc Kenzie 法 ${ }^{11)}$ にり測定した.

その結果は（Table 5) に示すように，D分画投与群に於ては，検体投与後 6 分，12分後に著明な TSH 活性の上昇を認めている.

所が， B 分画投与群では投与 3 分後に軽度の $\mathrm{TSH}$ 上昇をみるが，推計学的には有意ではない， $\mathrm{A}, \mathrm{C}, \mathrm{E}$, 分画投与群では TSH 上昇効果は全く認むられない. 以上の事よりD分画には TSH 上昇効果があるとい える.

Table 5. Changes in plasma TSH levels after injection of various fractions $(100 \mu \mathrm{g})$

\begin{tabular}{|c|c|c|c|}
\hline Fraction & $\begin{array}{l}\text { Time } \\
\text { min. }\end{array}$ & $\begin{array}{l}{ }^{131} \text { I Release from thyroid gland of mice } \\
\% \text { of initial blood }{ }^{131} \mathrm{I} \text { at } 2 \mathrm{hrs.} \pm \mathrm{S} . \mathrm{E} \text {. }\end{array}$ & $\begin{array}{l}\text { P-Value } \\
\text { compared with } \\
\text { control }\end{array}$ \\
\hline \multirow{4}{*}{ A } & 0 & $108.1 \pm 6.6$ & Control \\
\hline & 3 & $79.4 \pm 15.5$ & N.S. \\
\hline & 6 & $118.0 \pm 26.8$ & N.S. \\
\hline & 12 & $91.6 \pm 11.0$ & N.S. \\
\hline \multirow{4}{*}{ B } & 0 & $101.0 \pm 18.5$ & Control \\
\hline & 3 & $142.9 \pm 16.9$ & N.S. \\
\hline & 6 & $104.8 \pm 9.3$ & N.S. \\
\hline & 12 & $130.9 \pm 7.2$ & N.S. \\
\hline \multirow{4}{*}{$\mathrm{C}$} & 0 & $64.5 \pm 6.9$ & Control \\
\hline & 3 & $83.0 \pm 12.1$ & N.S. \\
\hline & 6 & $68.0 \pm 9.3$ & N.S. \\
\hline & 12 & $64.5 \pm 8.6$ & N.S. \\
\hline
\end{tabular}




\begin{tabular}{c|r|r|c}
\hline & 0 & $105.1 \pm 7.2$ & Control \\
$\mathrm{D}$ & 3 & $121.2 \pm 10.7$ & $\mathrm{~N} . \mathrm{S}$. \\
& 6 & $232.4 \pm 15.7$ & $<0.02$ \\
& 12 & $185.0 \pm 19.3$ & $<0.05$ \\
\hline \multirow{3}{*}{$\mathrm{E}$} & 0 & $86.2 \pm 5.1$ & Control \\
& 3 & $106.5 \pm 4.1$ & N.S . \\
& 6 & $108.5 \pm 14.1$ & N.S. \\
& 12 & $100.1 \pm 15.4$ & N.S . \\
\hline
\end{tabular}

\section{第 2 節 D 分画の TRF 効果の特異性について}

$\mathrm{D}$ 分画の $\mathrm{TSH}$ 上昇効果が果して D分画の TRF 作用に基づくものであるか, 或はD分画の中に TSH の

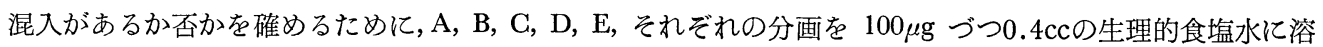
解して, そのままマウスの尾静脈内に投与して, 各分画の TSH 含量を測定した。 その結果, D分画に於て は, 他の A, G, E, 分画とともに TSH 活性は全く認められない, B 分画に於ては, 軽度の TSH 様効果 がみられたが，推計学的には有意とはいえない．乙れらの事実から，D分画には TSH の contamination はないと考えられる. (Table 6)

次にD分画がTSH を Potentiate したり，TSH の不活性化を抑制したりする作用があるか否かを確め るために, 血漿或は既知量の TSH にD分画を添加して, 非添加群と比較した。 その結果, 検定当日或は 24 時間前に血槳にD分画を添加しても，非添加との間飞差を認めず，又，既知量の TSH 亿検定当日或は 24時間前にD分画を添加しても非添加との間に差を認めない，乙れらの事より，D分画が TSH の活性を Potentiate したり，TSH の不活性化を抑制する作用をもたない事が判る. (Table 7)

Table 6. Absence of TSH effect in various fractions

\begin{tabular}{|c|c|c|c|}
\hline Fraction & Dosis & $\begin{array}{c}\% \text { of initial blood }{ }^{131} \mathrm{I} \text { at } 2 \mathrm{hr} . \\
\text { mean } \pm \text { S.E. }\end{array}$ & $\mathrm{P}$ \\
\hline Saline & $0.4 \mathrm{cc}$ & $83.1 \pm 12.1$ & Control \\
\hline A & $100 \mu \mathrm{g} / 0.4 \mathrm{cc}$ & $97.4 \pm 13.3$ & N.S. \\
\hline B & $100 \mu \mathrm{g} / 0.4 \mathrm{cc}$ & $150.1 \pm 16.9$ & $0.2>\mathbf{P}>0.1$ \\
\hline G & $100 \mu \mathrm{g} / 0.4 \mathrm{cc}$ & $115.1 \pm 14.7$ & N.S. \\
\hline $\mathrm{D}$ & $100 \mu \mathrm{g} / 0.4 \mathrm{cc}$ & $87.7 \pm 13.3$ & N.S. \\
\hline $\mathrm{E}$ & $100 \mu \mathrm{g} / 0.4 \mathrm{cc}$ & $87.1 \pm 15.3$ & N.S. \\
\hline
\end{tabular}

Table 7. Absence of TSH potentiating effect in fraction D

\begin{tabular}{|c|c|c|c|}
\hline Preparation (0.4cc vol) & Mixture & $\begin{array}{c}\% \text { of initial blood }{ }^{131} \mathrm{I} \text { at } 2 \mathrm{hr} . \\
\text { mean } \pm \text { S.E. }\end{array}$ & $\mathrm{P}$ \\
\hline Plasma & - & $108.0 \pm 9.4$ & Control \\
\hline Plasma +D $100 \mu \mathrm{g}$ & immediately after & $97.7 \pm 9.3$ & N.S. \\
\hline Plasma +D $100 \mu \mathrm{g}$ & $24 \mathrm{hrs}$ after & $111.0 \pm 9.6$ & N.S. \\
\hline TSH 0.4 musp & - & $235.0 \pm 33.6$ & Control \\
\hline TSH 0.4 musp $+\mathrm{D} 100 \mu \mathrm{g}$ & immediately after & $213.5 \pm 24.7$ & N.S. \\
\hline TSH 0.4 musp+D $100 \mu \mathrm{g}$ & $24 \mathrm{hrs}$ after & $228.0 \pm 21.6$ & N.S. \\
\hline
\end{tabular}


次に予め種々の前処置を行つたラットについてD分画を投与し，投与前及び投与 10 分後の血漿 TSH 活性 を Mc Kenzie 法で測定した. 即ち,

i ）両側視床下部を電気的に破壊した後 3 週間を経たラット.

ii）塩酸モルヒネ $6 \mathrm{mg}$ を $0.4 \mathrm{cc}$ の生理的食塩水に溶解したものを 3 日間皮下注射を行い，最後の注射の のち 4 時間を径たラット.

iii）下垂体剔除を行つたのち 3 週間を経たラット.

てれらの前処置を行つたラットについて，前節に記した方法に従つて頻静脈より $0.8 \mathrm{cc} の$ 前採血を行い，

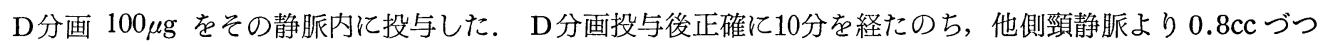
採血する. 一群 8 匹のラットについて，てれら D分画投与前及び投与後の血漿をそれぞれプールして，TSH 活性を測定した。 その結果は（Table 8) に示すように，両側視床下部を破壊したラットやモルヒネを投与 したラットに於ても，D分画は明らかな TSH 上昇効果を認めるが，垂剔を行つたラットではD分画を投与 しても血漿 TSH 活性の上昇は全く認められない.

Table 8. Effect of fraction $\mathrm{D}$ on various pretreated rats

\begin{tabular}{c|c|c|c}
\hline \multirow{2}{*}{ Pretreatment } & $\begin{array}{c}\text { Time } \\
\text { min. }\end{array}$ & $\begin{array}{r}\text { \% of initial blood }{ }^{131} \text { I at } 2 \mathrm{hrs.} \\
\pm \text { S.E. }\end{array}$ & $\mathrm{P}$ \\
\hline \hline \multirow{2}{*}{ Hypothal. lesion } & 0 & $89.7 \pm 17.0$ & Control \\
& 10 & $227.0 \pm 22.9$ & $\mathrm{P}<0.01$ \\
\hline \multirow{2}{*}{ Morphine } & 0 & $91.0 \pm 10.2$ & Control \\
& 10 & $205.8 \pm 8.5$ & $\mathrm{P}<0.05$ \\
\hline \multirow{3}{*}{ Hypophysectomized } & 0 & $122.0 \pm 18.1$ & Control \\
& 3 & $104.0 \pm 9.5$ & N.S . \\
& 6 & $98.1 \pm 17.0$ & N.S . \\
& 12 & $113.0 \pm 15.7$ & N.S . \\
\hline
\end{tabular}

尚これら実験の終了後に視床下部破壊及び下垂 体剔除が完全に行なはれているてとを確めた。

次に D 分画の種々の量をラットに投与して投与 10分後の血墏 TSH 活性を比較測定した. 即ち, 前節と同じようにして前採血を行つたラットに, $0 \mu \mathrm{g}, 10 \mu \mathrm{g}, 50 \mu \mathrm{g}, 100 \mu \mathrm{g}, 500 \mu \mathrm{g}$ ，のD分画をそれ ぞれ $0.4 \mathrm{cc}$ の生理的食塩水に溶解して頸静脈内に 投与し, 投与 10 分後の血漿 TSH 活性を測定した。 その結果は (Fig. 9) の如く，投与したD分画の量 と血漿 TSH 活性の間に用量反応関係が認められ る.

\section{第 3 節 D 分画の本態に関するクロマトグラフ ィーによる検索}

$\mathrm{D}$ 分画をブタノール:醋酸: 水 $=2: 1: 1$ 及び,
Fig. 9. Effect of varying dosis of fraction D on plasma TSH levels.

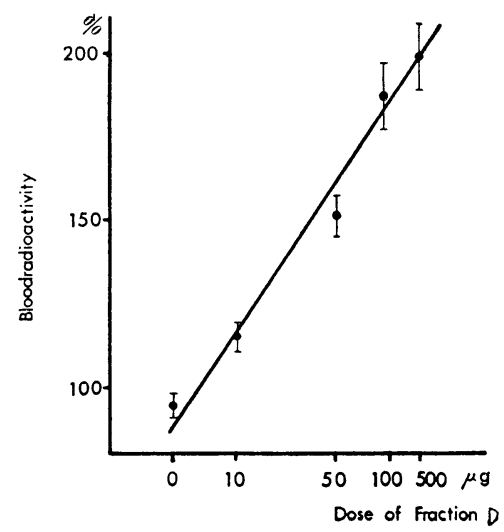
ブタノール：ピリジン: 水 $=1: 1: 1$ の溶媒で, 上 行法によりクロマトグラフィーを行つた後, ニンヒドリンで染色すると D分画は尚 $2 \sim 3$ ケの分画に分ち得 た. 
この場合, D分画の移動度は Adrenaline, Noradrenaline, Serotonin, Histamine, Acethylcoline, Bradykinin, Octapressin, Kallidin， $\alpha$-MSH 等とは移動度を異とするが, Lysine Vasopressin, Arginine Vasopressin とはその移動度が比較的近似している. (Fig. 10)

Fig. 10. Chromatographic comparison of fraction $\mathrm{D}$ with active amines and peptides.
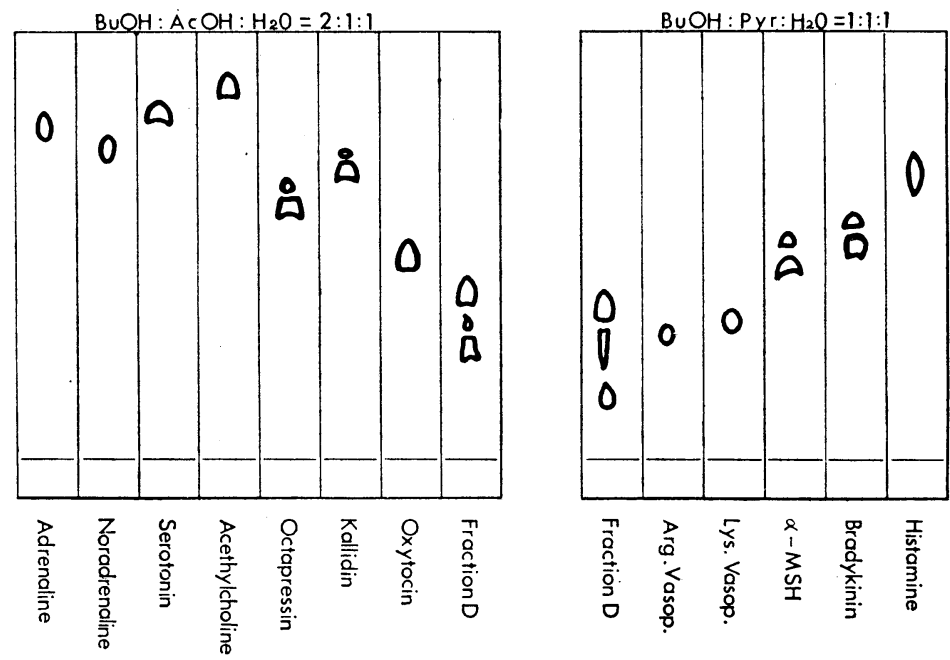

\section{（附） D 分画の構成アミノ酸について}

$\mathrm{D}$ 分画 $20 \mathrm{mg}$ を $6 \mathrm{~N}$ 塩酸で $110^{\circ} \mathrm{C}, 48$ 時間加水分解を行い，アミノ酸自働分析器により構成アミノ酸を检 討した所，14種のアミノ酸よりなる事が判つた。その構成ア々ノ酸の種類はL Lot No. による相違はなく, 又分析をお願いした各々の研究機関で一致している. (Table 9)

Table 9. Amino acid analysis of fraction D

\begin{tabular}{|c|c|c|c|c|c|c|}
\hline & \multicolumn{2}{|c|}{$\begin{array}{l}\text { Insitute for } \\
\text { protein resarch } \\
\text { Osaka Univ. } \\
\text { Lot No. } 6603\end{array}$} & \multicolumn{2}{|c|}{$\begin{array}{l}\text { Kobe Univ. } \\
\text { Lot No. } 6603\end{array}$} & \multicolumn{2}{|c|}{$\begin{array}{l}\text { Osaka Gity Univ. } \\
\text { Lot No. } 6504\end{array}$} \\
\hline 1 & Lys. & 6.4 & Lys. & 9.3 & Lys. & 6.4 \\
\hline 2 & His. & 3.0 & His. & 3.1 & His. & 5.2 \\
\hline 3 & Arg. & 3.4 & Arg. & 5.2 & Arg. & 3.6 \\
\hline 4 & Asp. & 12.0 & Asp. & 9.5 & Asp. & 12.7 \\
\hline 5 & Thr. & 4.9 & Thr. & 5.5 & Thr. & 5.5 \\
\hline 6 & Ser. & 7.9 & Ser. & 6.4 & Ser. & 3.7 \\
\hline 7 & Glu. & 9.3 & Glu. & 12.9 & Glu. & 7.6 \\
\hline 8 & Pro. & 6.1 & Pro. & 4.8 & Pro. & 4.4 \\
\hline 9 & Gly. & 9.0 & Gly. & 15.4 & Gly. & 5.3 \\
\hline 10 & Ala. & 136 & Ala. & 11.7 & Ala. & 10.0 \\
\hline 11 & Val. & 83 & Val. & 6.7 & Val. & 7.0 \\
\hline 12 & Iso. & 1.3 & Iso. & 0.9 & Iso. & 8.3 \\
\hline 13 & Leu. & 10.0 & Leu. & 7.6 & Leu. & 18.6 \\
\hline 14 & Phe. & 4.3 & Phe. & 1.9 & Phe. & 16.9 \\
\hline
\end{tabular}




\section{小 括}

A， B， C，D，E. のそれぞれの分画をラットに投与して血漿 TSH 活性のパターンを検討した所，D分画 投与群に於て著明な TSH 活性の上昇を認めた。 D分画にはTSHのcontamination はなく, TSH 活性を Potentiate したり，TSH の不活性化を抑制する作用もない，D分画は視床下部破壊を行つたラットやモル ヒネを投与したラットに於ても，著明な TSH 上昇効果を示すが，垂剔を行つたラットでは TSH 上昇効 果は全く認められない。即ち，D分画は内因性の TRF に㗢きかけないで，直接下垂体に働くものである 事を示している. 更にD分画には用量反応関係が認められる. てれらの事から D分画の TRF 効果は特異的 なものであるといえる. そして，ての分画の本態はクロマトグラフィーで調べると，Vasopressin とは比較 的近似した移動度を示すが，その他の活性アミン類や peptide とは移動度が異つている。

\section{考按}

臨床的に甲状腺機能や甲状腺疾患が環境や外界刺激により影響を受ける事は, 古くより知られている所で ある. 一方, 実験的にも大脳の核の破壊 ${ }^{15)}$, 大脳辺縁系の刺激 ${ }^{16)}$ が, 甲状腺機能に影響を与える事実は, 中枢神経系と甲状腺との間に密接な連絡がある事を暗示している。この場合, 中枢神経系と甲状腺を結ぶ経路 として, 次の二通りの道が想定される. その一つは, 神経系一視床下部一下垂体一甲状腺の経路であり, 他 の一つは，視床下部自律神経中枢を介した自律神経による甲状腺への連絡である．ての第一の経路に於て問 題となるのは, 神経系と内分必系の接触している視床下部と下垂体との結びつきである. 視床下部と下垂体 甲状腺系の関係をみた実験として

1）動物を寒冷暴露の状態におくと甲状腺腫が現われるが, 柄切離を行つた動物では甲状腺腫が出現しな $\left(^{17)}\right.$.

2) 下垂体を視床下部から切離して移植すると甲状腺が萎縮する ${ }^{18) 199}$.

3）視床下部を刺激すると TSH 分泌が充進する20221).

4) 視床下部を破坮すると TSH 分蜜が減少する22233.

これらの事実は視床下部と下垂体甲状腺系の間に密接な関係のある事を示している。乙の場合, 下垂体前葉 には分泌神経が存在しないとと, 及び視床下部と下垂体との間には下垂体門脈が存在し, その流れの方向は 視床下部より下行性に前葉に向つて流れている事実は, 視床下部と下垂体との関係が神経性に連絡されてい るのではなく，視床下部の神経終末で放出された液性因子（RF）が，中央隆起の下垂体門脈の第一次毛細 管叢にとりこまれ，門脈を介して前葉に達し，TSH の分泌を促がすという考え方の根処となつている。乙 の下垂体門脈の働きについても, Brown-Grant ${ }^{24)} や$ Purves $^{25)}$ は視床下部は中央隆起の第一次毛細管叢で甲状 腺ホルモンとを沪過し, 或は甲状腺ホルモンと結合するような物質を出して, 下垂体へ行く甲状腺ホルモン を抑光，Feed Back によりTSH の分泌を抑制しているのであろうといつている.

所がての様な Feed Back による沪過説で視床下部の機能を説明しようとすると，前述の1）〜 4) の実 験の説明が困難である. 更に, 甲状腺ホルモンの Feed Back は視床下部以外に, 下垂体自身も Feed Back の receptor となりうる ${ }^{26227)}$. その上, 最近の視床下部抽出物に TSH 放出作用があるという報告と共に, 柄切離や下垂体移殖の実験で明らかなように，下垂体が視床下部下垂体門脈との結合によつてのみその機能 が維持されるという事実は，下垂体門脈の中に TSH 分泌を促進する或特殊な液性因子が含まれているため であると考えざるを得ない.Harris ${ }^{19)}$ が下垂体門脈の存在を強調して以来, 視床下部の液性因子が前葉ホルモ ンを分泌させるという考え方は既に一般化しており, 門脈の周囲や門脈腔内, 更に前葉の Pars distalis 亿 も, 視床下部液性因子と密接な関係にあると考元られている神経分泌物の存在が涊められている ${ }^{2829)}$. ての 神経分泌物の本態についても，後葉ホルモンであるとか，その担体であるとかいわれているが，視床下部に 液性因子が存在するという一つの有力な根拠となつている.

視床下部液性因子の本態として以前は, Adrenaline, Noradrenaline, Serotonin, Histamin, Acethylcoline 等が問題となつたが, 近年最も注目されたものは後葉ホルモンである. 後葉ホルモンが視床下部に存 
在する事は既に多くの学者によつて認められている所であり, それ故, 後葉ホルモンと下垂体甲状腺系の関 係を榆討した報告も多い，所が，後葉ホルモンの下垂体甲状腺系に対する効果については，後葉ホルモンが 下垂体甲状腺機能を古進させるとするもの，影響がないというもの，或は反対に低下させるとする報告等が あり，意見の一致をみていない.

Vasopressin 以外の既知物質として最近，MSH が問題となつているが，MSH の下垂体甲状腺作用につ いて, Guillemin ${ }^{31}$ らは in vitro, in vivo の実験に於て否定的な結果を得ており, Schally ${ }^{30)}$ にると仮に MSH が多少の向妇状腺効果を有していても，それは甲状腺への直接作用であろうと推定している。 TRF の存在が理論的には認められておりながら, 既知の活性アミン類や, 後葉ホルモンにTRF 効果がないとす るならば，TRF の探究は当然視床下部そのものから TRF を抽出分離していく方法に頼らざるを得ない. Azzali $^{32) 33)}$ ，Ragnose ${ }^{34)}$, Petrovic ${ }^{35)}$, Bachrach ${ }^{36)}$ らは in vivo，in vitro の実験で視床下部抽出物を与えると 甲状腺機能立進効果が起ることを観察しているが，乙れらの抽出物は下垂体を介さず甲状腺への直接作用に よるものであるという。

涉汇 ${ }^{37738383940)}$ らは犬の視床下部の水抽出物から, 下垂体 TSH を放出させる作用のある物質をとり出し, とのものが視床下部の神経分泌細胞で生産され，血液を介して主として尿に排出されるという．所が， Reichlin ${ }^{41}$ らは，乙の䠖沢らの TRF をラットに投与して，血槳 TSH 量を Mc Kenzie 法 ${ }^{11)}$ で測定したが, 有意の増加を誌めなかつたとしている.

Odell ${ }^{42)}$ は鬼の甲状腺を培養し, てれに視床下部と下垂体を加光ると, 下垂体のみを加えた時よりも甲状 腺の重量の減少が抑制される事実を認め，てれは視床下部に TRF が含まれているためであろうと考えた. Flosheim ${ }^{43}$ はマウスの下垂体の短時間 incubation 標本に視床下部粗エキスを添加しても，何等影響をみな かつたといつているが，Mc Kenzie ${ }^{44)}$ はラット下垂体を同様に incubation し，視床下部粗エキスを添加す ると, medium 中への TSH 放出が促進されるという. Meites ${ }^{45) 46}$ は in vitro で incubation したラット の下垂体に視床下部粗エキスを添加すると, 下垂体より放出された TSH の量が，加えた視床下部の量と相 関々係にある事をみている。

以上の様な視床下部粗エキスの TRF 効果を検討する段階から, 更に進んで TRF の純化を試みた報告 は著者らの他に, Schreiber, Guillemin, Schally らの報告があるのみである.

Schreiber ${ }^{4778) 49)}$ は in vitro で incubate したラット下垂体に，視床下部の醋酸抽出物を加えると，下垂 体の酸性フォスファターゼ活性が上昇すること，又，下垂体の酸性フォスファターゼ活性と下垂体 TSH 産

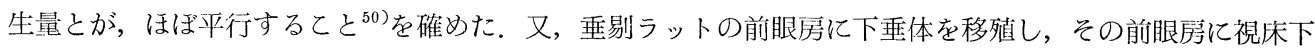
部抽出物を投与すると，副腎や性腺は菱縮するが，甲状腺の萎縮は抑えられるという ${ }^{51}$. 彼等はとの有効 物質を精製するために，視床下部醋酸抽出物を高圧汇紙電気泳動で分画化して得た分画が，in vitroの下垂 体の酸性フォスファターゼ活性を高めること ${ }^{52)}$ ，及びラットの下垂体を短時間 incubation して medium 中の TSH 量を Eckertova 法 ${ }^{53}$ で測定したとてろ, ての分画が有意の TSH 効果を示すととをみた ${ }^{54}$. 又, この有効分画を Sephadex G25 のカラムで純化したものが in vivo のラット ${ }^{131} I$ 放出法 ${ }^{7)}$ に於ても , in vitro の下垂体 incubation 法に於ても有意の TSH 放出効果のあるととを確めた ${ }^{5556)}$. そして，ての有効 分画は下垂体 TSH の合成と放出に働くものであり，ての物質の本態は８ケのアミノ酸よりなる peptide で あり，後葉ホルモンや TSH 或は他の既知物質とは異なるものであるという ${ }^{8757587 .}$

1962年来, Guillemin らは羊の視床下部の醋酸抽出物を Sephadex G25 のカラムを用いて分画化し，in vivo で TRF 活性を示す分画を得た ${ }^{59960)}$. 乙の分画を凍結乾燥したもの $1 \mathrm{mg}$ の示す TRF 活性を 1TRF 単位として用いている ${ }^{61)}$. 佊等は更にての方法で得られた TRF を， CMC カラムを用いて精製し ${ }^{62}$ ， in vitro の短時間下垂体 incubation 標本飞添加すると, medium 中の TSH が増量しているとと, この有 効物質の作用機序は下垂体自身の TSH 放出を促進するものであつて，TSH を potentiate した結果では ない事を確めた。 そして, ての有効物質の本態は GRF, GRF, Oxytocin, Vasopressin, MSH 等とは異つ たものであるという ${ }^{63)}$.更に Guillemin ${ }^{64)}$ らは TRF の純化を目的として,大量の羊の視床下部の醋酸抽出物 
を, Sephadex G25 カラム, 交流分配法, IRG カラム, 薄風クロマトの順に純化精製し, このものが11種 類のアミノ酸よりなる Peptide であるとと, 又, てのものには GRF 作用や GRF 作用がない事を確めた ${ }^{65) 66)}$. ごく最近に到つて彼等はTRF の分離にイオン交換 Sephadex を使用する事を試みており，醋酸で 抽出した羊視床下部を，Sephadex G25, CM-Sephadex G50, Sephadex G25 の順にクロマトを行い, Norit $\mathrm{A}$ 吸着，エタノール溶出して薄首クロマトにかける方法で，極めて高い活性を有する TRF の抽出に成功し たという ${ }^{67) 68)}$.

1965年以降に，Schally らは豚，牛，羊等の視床下部の醋酸抽出物を Sephadex G25 で分画抽出したも のが， in vitro の下垂体短時間 incubation 法 ${ }^{69)}$ 及び in vivo の甲剔ラット TSH を指標とする方法で TRF 効果を示すととを報告した ${ }^{70) 71)}$. 更にマウス血中 ${ }^{131} \mathrm{I}$ 莀度を指標とする方法 ${ }^{72)}$ によて，乙の抽出 物の最少有效量が $100 \mu \mathrm{g}$ であることを兒出した ${ }^{73)}$. 次でての分画をフェノールで抽出し， GMC カラムを 通すととにより, TRF 活性を有する14種類のアミノ酸よりなる塩基性ペプチッドの抽出に成功した ${ }^{74)}$.

後葉ホルモンが視床下部で作られており，又同一臟器よりの分泌物は比較的類似しているという生物体の 法則より考えると，後葉ホルモン，RF 等は互に類似した物質ではないかと想像される．又，臟器抽出 $\mathrm{Va}$ sopressin (Pitressin) の中には視床下部由来と思はれる RF が contaminate されているととも想像されて いるので，視床下部を直接後葉ホルモンの抽出法に従つて抽出すれば，てれらの Contaminant がより高濃 度で抽出されると考えられる.

以上の観点より著者は, 犬, 鬼, ラット, 解, 牛等の視床下部を Kamm Aldrich の方法に従つて抽出し たところ, 比較的, 大量の材料の得られる牛視床下部抽出物に於て, 抗利尿活性, 並びに TRF 活性を認め 得た。この場合, 䐟器抽出物の非特異反応を検討するために, すべての実験に於て前視床下部, 後視床下部, 大脳皮質等を同じ方法で抽出し，又，同一の方法で生物学的活性の検定を行つた.

ての結果，前視床下部抽出物に於てのみ，抗利尿効果及び下垂体甲状腺機能立進効果を認めた。 そして， 視床下部抽出物の甲状腺効果は垂剔ラットには効果がなく, 又直接血漿 TSH を上昇させる作用のある事よ り，本抽出物は下垂体に衝いて TSH を放出させるものであると考えられる.

この場合，前視床下部抽出物の TSH 上昇効果が，視床下部由来の抗利尿ホルモンに基づくのか，或は別 の物質に基くものであるかか問題となる，そこで，DEAE-Sephadex を用いてての前視床下部粗エキスを分 画化した所, 尚, D分画に於て抗利尿効果と TRF 效果の重複を認めた. 所がD分画 $1 \mathrm{mg}$ は強力な TRF 效果を示すが，その抗利尿活性は Lysine Vasopressin として約 $0.09 \mathrm{mu}$ の抗利尿活性を有するにすぎない. 一方, Lysine Vasopressin のみではその程度の量では勿論のとと，その10倍，100倍，1000倍の量を投与 しても，TSH 上昇効果を認めない.

それ故，D分画の TRF 効果はV Vasopressin によるものとは考えられない. Guillemin ${ }^{59) 64)} や S^{2}$ (chally ${ }^{74)}$ の最近の報告に於ても，TRF とVasopressin 分画は極めて接近して検出されており，著者のD分画の抗 利尿活性は, 微量の Vasopressin の混入によるものか, 或は大量の TRF はアミノ酸構成の類似のために, 抗利尿活性を示したものと考えられる。事実, Sephadex G25 を用いた Long カラムでD分画を更に再分 画すると，TRF 活性を示す分画と抗利尿活性を示す分画は分離しうる事，又，種々の量の Lysine Vasopressin, Arginine Vasopressin をラットの頸静脈に投与しても血漿 TSH の上昇を認めない事実等 ${ }^{75)}$ か ら，D分画の $\mathrm{TRF}$ 効果は $\mathrm{ADH}$ によるものではないといえる。 又，D分画を垂剔動物に投与しても甲状 腺効果は勿論のとと，血漿 TSH 活性の上昇を全く認めず，更に，D分画の TSH 活性を Mc Kenzie 法で 測定しても TSH 活性は全く認められない.

これらの事からD分画には TSH の contamination はないといえる. 次に両側視床下部を電気的に破壊 したラットやモルモヒネを投与したラットに於てもD分画は明らかな TSH 放出效果を示すが，垂剔ラット ではその効果がなく，D分画の投与量と TSH 増量の間に $10 \mu \mathrm{g} \sim 500 \mu \mathrm{g}$ の間で用量反応関係が成立してい る. 又, D分画は in vitro で培養した下垂体に於ても，TSH 放出効果が認められている ${ }^{75)}$. このように D分画は TSH の contamination をもたず，TSH を末梢に於て potentiate せず，内因性の TRF に働 
きかけないで，下垂体に直接作用して TSH を放出させ，且つ，用量反応関係を示すととから，D分画の TRF 効果は特異なものであり，既知の活性アミン類やペプタイドとは活性の上からもクロマトに於ける移 動態度からも異つた物質であると考光られる．D分画がクロマトにより尚３ケのスポットに分れるとと，D 分画の構成アミノ酸は14種であるが，D分画を更に Sephadex G25 を用いた Long カラムで再分画した時 に，TRF 活性を示す分画（D II 分画）の構成アミノ酸は11種であるとと ${ }^{75)}$ ，等から考えてD分画は更に精 製の余地があると考えられる.

\section{結語}

1) 牛の前及び後視床下部, 頭頂葉皮質を Kamm Aldrich の方法に従つて抽出した所, 前視床下部抽出 物に於て，抗利尿効果及び甲状腺機能六進効果を認めた.

2 ）乙の前視床下部抽出物の甲状腺効果は，垂剔動物には効果がなく，又直接血漿 TSH 様活性を上昇さ せる事より，本抽出物は下垂体 TSH を介して甲状腺に衝いているといえる.

3 ）乙の前視床下部抽出物は電気泳動により尚, 数ヶの分画に分離しうる。そてで, DEAE-Sephadexを 用いたカラムクロマトで，ての前視床下部抽出物を分画化すると，A， B , C , D , E の 5 ケの分画に分離しえた.

4）以上 5 ケの分画のうち，抗利尿活性はD分画，次で A 分画住認められ，甲状腺 ${ }^{131} \mathrm{I}$ 放出促進効果は， $\mathrm{D}$ 分画次で B 分画隹認め引る.

5 ）それぞれの分画をラットに投与して，血漿TSH のパターンを調べた所，D分画投与群に於てのみ著 明な TSH 上昇効果を認めた。

6) D分画の TRF 効果は特異なものであり, 又, その本態は後葉ホルモンや既知のペプタイド, 活性ア ミン等とは異つたもである.

稿を終えるに当り, 終始御想篤な御指導と激励を睗り, 又御校閲を睗つた恩師, 辻昇三教授に深甚な感謝 の意を表します。, 又, 直接実験に御協力御指導を晹つた佐古田博士をはじめ, 間脳研究班の諸先生に心から の謝意を表します, 又, 特飞電気泳動の御指導を踢わつた神戸女子菲大, 橋本庸平教授, 森五彦博士, 及び 抗利尿ホルモンの抽出を御指導下さつた帝国制器, 松島早苗博士, Sehadex, MSH 等の提供を頂いた Dr. Schreiber, Dr. Schally, 飞厚く御礼申し上げます。

尚本論文の要旨は第 34 回, 第 38 回, 第40回日本内分泌学会総会, 及び第 10 回, 第 14 回西日本内分泌学会に 於て発表した。

\section{文献}

1) KAMM, O., ALDRIGH, T.B., GROTE, I.W., ROWE, L.W., and E.P. BUGBEE : J. Am. Chem. Soc. 50, 573, (1928)

2) VANDYKE, H.B., K. ADAMSONS, J.R., and S.L. ENGEL : Rec.

Prog. in Horm. Res. 11, 1, (1955)

糸賀宣三：ホルモンと臨床，8，135，

Endocrinol 43, 306, (1948)
3) DICKER, S.E. : J. physiol. 122, 149, (1953) SCHREIBER, V., ECKERTHES : J. physiol. 151,40, (1960) 8) SCHREIBER, V., ECKERTOVA, A., FRANC, E., RYBAK, M., GREGOROVA, I., KMENTOVA, V., and V. JIRGL : Physiol. Bochemoslov. 12, 1, 1963

9）田中 明: 塩野義研究所年報, 第 5 号, (1957) 10）小倉 一：日本内科学会雑誌，48，1045，(1959）

11) Mc KENZIE,

J.M. : Endocrinol 63, 372, (1958)

Biochem. zeitsch. 323, 345, (1952)

nschaften 37,496 , (1950)

163, 292, (1949)

MATSUZAKI, F., IINO, S., MATSUDA, K., NAGATAKI S., and S. OKINAKA : Endocrinol 7l,

12) HOLT, G.V., VDIGT, K.D., and K. GAEDE :

13) GRASSMANN, W., and K. HANNIG : Naturwisse- 
456, (1962)

17) UOTILA, U.U. : Endocrinol. 25, 605, (1939)

18) NIKITOVITGH, W., and L.J.W. EVERRET : Endocrinol. 65, 357, (1959) 19) HARRIS, G.W. : Neural Control of the Pituitary Gland, Edward Arnold Publ Ltd., London (1955) 20) HARRIS, G.W., and J.W. WOOD : Ciba found, Colloq on endocrinol. 10, 3, (1957)

21) SHIZUME, K., MATSUDA, K., IRIE, M., IINO, S., ISHII, J., NAGATAKI, S., MATSUZAKI, F., and S. OKINAKA : Endocrinol 70, 298, (1962) 22) REICHRIN, S. : Endocrinol 66, 340, (1960)

23) AVERILL, R.L.W., PURVES, H.D., and N.E. SIRETT : Endocrinol 69, 735, (1961)

24) BROWN GRANT, K., : Giba Found, Golloq on Endocrinol. 10, 97, (1957)

25) PURVES, H.D. : Acta Endocrinol. Supple. 50, 21, (1960) 26) D'ANGELO, S.A. : J. of Endocrinol. 17, 286, (1958) 27) VON EULER, G., and G. HOLMGREN : J. Physiol. 131, 125, (1956) 28）野田秀俊 : 日 本内分泌学会雑誌，32，509，（1956） 29) SHIBUSAWA, K., SAITO, S., FUKUDA, M., KAWAI, T., and F. YOSHIMURA : Endocrinol. Jap. 2, 47, (1955) REDDING, T.W., and A.V. SGHALLY : Endocrinol. 74, 559, 1964 SAKIZ, E., and R. GUILLEMIN : Annales de Endocrinol. 24, 795, (1963) 30) BOWERS, G.X., 31) YAMAZAKI, E., 32) AZZALI, G. : Acta Neuroveg. 13, 456, (1956) 33) .OTTAVIANI, G., and G. AZZALI : Acta Neuroveg. 13, 80, (1956) 34) RAGNOSE, P. : Excerepta Med. Endocrinol. 13, 504, (1959) PETROVIG, A., and A. PORTE : C.R. Soc. Biol. 157, 1051, (1963)

36) BAGHRGH, D., LASZLO, A., SYABO, E.B., PETTKO, E., and B. KORPASSY : Nature 194, 538, 1962 SHIBUSAWA, K., SAITO, S., NISHI, K., YAMAMOTO, T., TOMIZAWA, K., and G. ABE : Endocrinol. Jap. 3, 116, (1956) 38) SHIBUSAWA, K., SAITO, S., NISHI, K., YAMAMOTO, T., and K. TOMIZAWA : Endocrinol. Jap. 3, 138, (1956)

39）山本隆信：日本内分泌学会雑 誌，33，870，(1958） 40）渋沢喜守雄：最新医学，16，727，(1961）

S., BOSHANS, R.G., and J.G. BROWN : Endocrinol. 72, 334, 1963

41) REIGHLIN, Endocrinol. 72, 39, (1963) 43) FLOSHEIM, W.H., IMAGAWA, D.T., and M.A. GREER : Proc. Soc. Exp. Biol. Med. 95, 664, (1957) 44) SOLOMON, S.H., and J.M. Mc KENZIE : Endocrinol. 78, 699, 1966 45) SINHA, D., and J. MEITES : Fed. Proc. 24, 128, (1965) 46) SINHA, D., and J. MEITES : Endocrinol. 78, 1002, (1966) 47) SCHREIBER, V., RYBAK, M., GHAVAT, J., and V. KMENTOVA : Physiol. Bochemoslov. 8, 291, (1959) 48) CHARVAT, J., SCHREIBER, V., and V. KMENTOVA : Nature 182, 62, (1958) 49) SGHREIBER, V., RYBAK, M., CHARVAT, J., and V. KMENTOVA : Nature 183, 473, (1959) 50) SCHREIBER, V., and V. KMENTOVA : Endocrinol. 38, 69, (1959) 51) SGHREIBER, V., RYBAK, M., and V. KMENTOVA : Experientia 16, 466, (1960) 52) SCHREIBER, V., KOGI, J., EGKertovA, A., FRANG, Z., and V. KMENTOVA : Physiol. Bochemoslov. 10, 417, (1961) 53) EGKERTOVA, A., and Z. FRANG : G.S.I. Fysiologie 10, 48, (1961) 54) SGHREIBER, V., EGKERTOVA, A., FRANG, Z., KOGI, J., RYBAK, M., and V. KMENTOVA : Experientia 17, 264, (1961) moslov. 12, 358, (1963) 55) SCHREIBER, V., and V. KMENTOVA : Physiol. BocheKOCI, V., KOGI, J, ERANG, Z, and V. KMENTOVA : Experientia 18, 338, (1962) SCHREIBER, V., RYBAK, M., KOCI, J., EGKERTOVA, A., FRANG, Z., JIRGL, V., KMENTOVA, V., KAPITOLA, J., SEBESIK, V., and V. KMENTOVA : Acta Univ. Carol. Ser. Med. Supple. 17, 105, (1963) 58) SCHREIBER, V. : Ann, d, Endocrinol. 25, 3I5, (1964) GUILlEMIN, R., YAMAZAKI, E., JUTISZ, M., and E. SAKIZ : G.R. Aced Sci. 255, 1018, (1962) 60) GUILlemin, R. : J.de. Physiol. 55, 26, (1963) 61) GUILLEMIN, R., and E. SAKIZ : 
Nature 207, 297, (1965)

62) JUTISZ, M., YAMAZAKI, E., BERALAT, A., SAKIZ, E., and

R. GUILLEMIN : C.R. Acad. Sci. 256, 2925, (1963)

63) GUILLEMIN, R., YAMAZAKI,

E., GARD, D.A., JUTISE, M., and E. SAKIZ : Endocrinol. 73, 564, (1963)

64) GUILLEMIN,

R., SAKIZ, E., and D.N. WARD : Proc. Soc. exp. Biol. med. 118, 1132, (1965)

65) DUCOM-

MUN,R., SAKIZ, E., and R. GUILLEMIN : Endocrinol. 77, 792, (1965)

66) SAKIZ, E.,

and R. GUILLEMIN : Endocrinol. 77, 797, (1965)

67) BURGUS, R., STILLWELL, R.N., MCGLOSKEY, J.A., WARD, D.N., SAKIZ, E., and R. GUILLEMIN : The physiologist. 9, 149, (1966) 68) GUILlEMIN, R., BURGUS, R., SAKIZ, E., and D.N. WARD : C.R. Acad, sci. 262, 2278, (1966)

69) SAFFrAN, M., and A.V. SCHALLY : Cand. J. Bioch.Physiol. 33, 408,

70) BOWER, C.R., REDDING, T.W., and A.V. SGHALLY : Endocrinol. 77, 609,

Med. 121, 718, (1966)

71) SGHAlly, A.V., REDDING, T.W., and G.Y. BOWERS : Fed. Proc. 24, 191, 78, 726, (1966)

72) REDDING, T.W., BOWERS, C.Y., and A.V. SGHALLY : Endocrinol. 79, 229,

73) SGHALly, A.V., BOWERS, C.Y., and T.W. REDDING : Proc, Soc, Exp. Biol.

(1967) 74) SCHALLY, A.V., BOWERS, C.Y., andT.W. REDDING : Endocrinol. 75）佐古田雅弘：第17回日本医学会総会学術諈演集，日本医書出版，東京III，322, 